\title{
静電容量式ボイド率計の高温高圧条件への適用研究*
}

\author{
渡 辺 博 典*1, 光 武 \\ 柴田光 彦*1, 高 瀬 和 之*3

\section{Experimental Study on Capacitance Void Fraction Meters for High Temperature and High Pressure Conditions} \\ Hironori WATANABE*4, Toru MITSUTAKE, \\ Mitsuhiko SIBATA and Kazuyuki TAKASE \\ ${ }^{* 4}$ Japan Atomic Energy Agency, \\ 2-4 Shirakatashirane, Tokai-mura, Naka-gun, Ibaraki, 319-1195 Japan

\begin{abstract}
The electro-void fraction meter (Capacitance type meter) was applied to higher pressure conditions of $18 \mathrm{MPa}$ than BWR operating conditions of $7 \mathrm{MPa}$. The void fraction measurement system has been developed including the electrodes of void fraction measurement, instrumentation cables with mineral insulation and simplified electric circuit to provide good signal-to-noise ratio. It satisfied the performance of thermal and pressure resistance and electric insulating capacity. Calibration function for high temperature and high pressure conditions was confirmed through calibration test with 37-rod bundle against datum 19-rod bundle by the quick-shut valve method respectively under $2 \mathrm{MPa}$ conditions. It was confirmed that the measured data were consistent with those measured by the quick-shut valve method.
\end{abstract}

Key Words : Void Fraction, Gas-Liquid Two-Phase Flow, Boiling, Internal Flow, Electrode

\section{1. 緒 言}

流路チャンネル内の気相が占める体積率 (ボイド率) は，気液二相流の諸特性を明らかにするために重要な 特性量であるため，様々な計測が行われてきた ${ }^{(1)-(3)}$. 原子力開発分野においては，高温高圧条件下の計測と なるため流路内にプローブを設置することが難しいこ とから，X線や $\gamma$ 線などの放射線を用いたボイド率測 定法が開発されてきた ${ }^{(2)}$. (3) しかし，計測系が高価と なることや設置場所が限られることなどのため, より 実用的な手法が求められていた。

軽水炉や新型炬の設計開発に適用可能なボイド率測 定手法は高温高圧条件下において次の特性を有するこ とが望まれる。

（1）純水環境中で使用できること.

（2）ボイト率測定範用㲎はぼ0〜100\%であること.

(3) 瞬持(リアルタイム)に測定できること.

（4）計測電極サイズが小さく，微弱钶号となる場合でも SN 比か確保されること

(5) 局所計測だけではなく流路断面の大域的なボイド率が 測定できること.

著者らは，沸騰水型軽水炬 (BWR) 炉心㽵力条件 $(7 \mathrm{MPa})$ に

* 原稿受付 2009 年 12 月 28 日。

*1 (独) 日本原子力研究開発機構 (恶319-1195 茨城県那珂郡東 海村白方白根 2-4).

*2 正員, (独) 日本原子力研究開発機構[現：(株)東芝(造2358523 横浜市磯子区新杉田町 8) ]

*3 正員, (独) 日本原子力研究開発機構.

E-mai1: watanabe.hironori@jaea.go.jp
おいて，流体の電気抵抗を測定する電気抵抗検出型ボイド 率計(以下R計測法)を適用したボイド率さ0.5sec. 毎に 測定し，核熱水力フィードバック効果を模擬して出力を変 化させた ${ }^{(1)}$ ，試験で検出感度上 $20 \mu \mathrm{S} / \mathrm{cm}$ 以上O導電性 水質とするため, 圾験用水にヒドラジン溶液 $\left(\mathrm{N}_{2} \mathrm{H}_{4}\right)$ を混入し た これは $50 \%$ 以上のボイト率て電王 $100 \mathrm{~V}$ に対して測定值 が $1 \mathrm{~mA}$ 以上になる導電率であるが，表面有食により1 ケ月 以上の耐用性がなかった。 また，高ボイド率(70〜80\%以上) では電栖間の水のパス (パーコレーション)が失われて信 号が遮断されるため, 測定範用加限られるという課題があ った この課題を解决するため静電容量検出型(以下 $C$ 計測 法をを適用し, 純水環境下の測定が可能となること, ボイド 率測定範用方拡大できることを示した(7)。

本研究では, 高速堌殖炉(FBR)の主要機器である蒸気発生 器の熱水力設計の基醍で一夕取得のため, 模擬試験ループ 二次側水一蒸気一相流のボイト摔測定方法の開発を行った. 圧力はBWR炻心条件より高、18MPaであることからボイ ト淬測定は著者の知る限り報告されたことがなかった 計 測上の難点は7MPa までの圧力条件に比べて飽和温度が高 く, 電極劣化の進行が早いこと, 水一蒸気の密度比が小さく なることから測定信号レベルが低く、SN 比が小さいなどが 考えられた. そこで本研究で性，C計測法を適用したボイ ト計測電極部・信号線の設計，計測回路の簡素化を行い， 圧力 $18 \mathrm{MPa}$ 条件のボイド率を測定することができたささら に，C計測法測定值の妥当性を確認するため，ボイド率測 
定值と急速遮断弁法による測定值を比較したのでその結果 老示市.

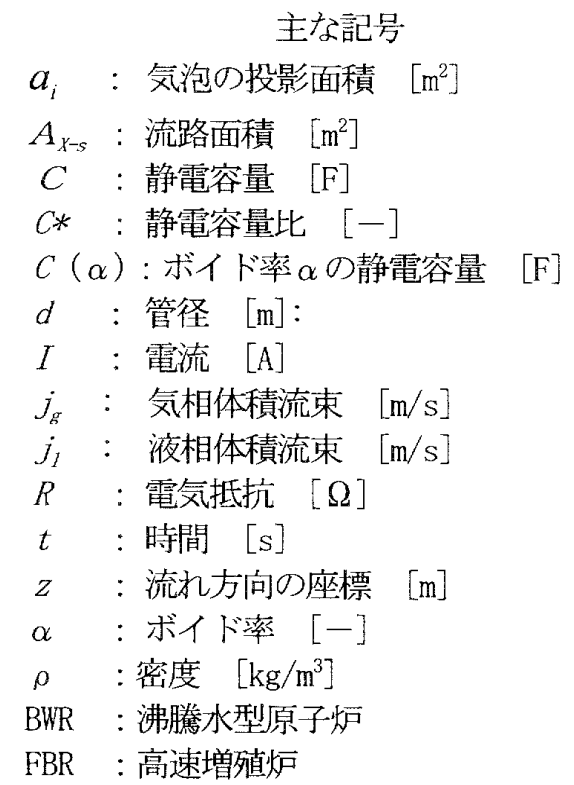

添字:

$\alpha=0, \quad \ell:$ 水単相状態

$\alpha=100, g:$ 気相単相状態

$\circ$ : 基準值

$X^{-S}$ : 断面

$T-S \quad$ : 試験部

\section{C計測法によるボイド率測定 一高温高圧条件への適用化一}

\section{1 単管試験装置 (18Ma 蒸気発生器流動試験装}

置) 試験部梳高速堌殖炉(FBR)の蒸気発生器細管 を模擬した 2 重管構造の垂直細管で, 流路内径 $11.6 \mathrm{~mm}$, 全長 $12.6 \mathrm{~m} の$ SUS 製中空管であり, 外周に設置した輻 射加熱ヒ一夕により間接的に加熱される．図 1 に試験 部構成と概観写真を示守.

2.2 ボイド測定部 軽水炉炉心模擬試験部 ${ }^{(10)}$ で は電気絶縁用のセラミック製シュラウドを試験流路内 面に刘向するように取り付けたが，本試験では，細径 管のセラミック製シュラウドの製作が困難であったの で，四 2 に示すように流路内に対面するように一対の 円板状電極(值径 $6 \mathrm{~mm}$, 肉厚 $1 \mathrm{~mm}$ )を流れ方向 3 ヶ所に 設置した. 図 1 下に差王計測ノズルとともにボイド率 計測ノズルを示す，図 1 下は，図 2 に示扗板上電極 を計测ノズルに組み込んだ状態を示守。電極リード線 は流れを阻害しないように細くし, 流路部挿入線の外 径は $2 \mathrm{~mm}$ とした。電極には交流抵抗計(LCR 計)を用いて 高周波定電圧を印加した。ボイド率は二相流のC成分 の測定値から特性式に基づいて測定した。

(1) MI シ一ス型電梗 電極认耐高温・耐高圧・ 電気絶縁性・酎久性を確保するため, 絶縁材を装填し
たセラミック端子付MI (Mineral Insulator) シース を用いて設計した. 図2にMIシース型電極写真を示す。 電極検出部は 2 枚の電極を $2 \mathrm{~mm}$ 閒隔で対向設置した. 信号取り出し線はシース型MI ケーブルで, 芯線が信号 線である，電極側芯線と金属シ一スは一体構造である ため, 電気絶縁確保上, 電極近傍のシースに切れ目を いれてセラミック管で接合した．接合ではシースとセ ラミック双方に接合できる中間金属（コバール）を用 いた. また, セラミックとシースは熱膨長率が等しく, 熱応力に起因するクラック発生を防止できるので, 高 温而久性が確保できた. 電極製作の過程では複数体を 試作し，高温高圧オートクレーブで而久性試験を行っ て上述の部材を決定した。これらの工夫により $18 \mathrm{MPa}$ の条件下で電気絶縁性・高温高玨耐久性が確保される ことが確認された.

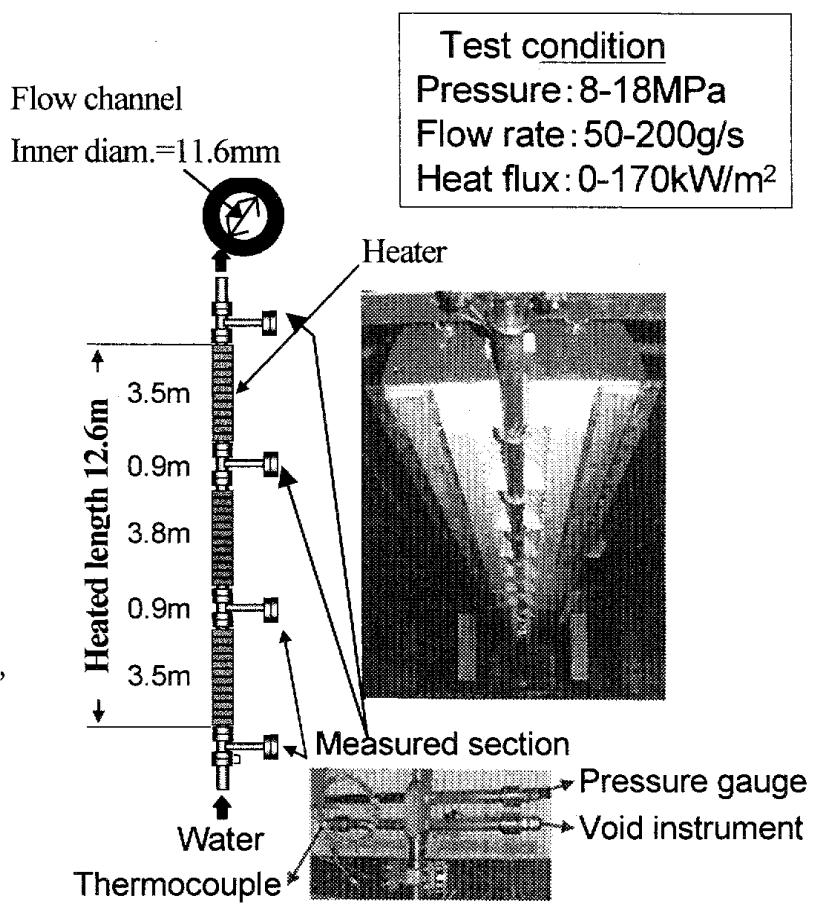

Fig. 1 Test section and test condition (13)

（2）計測信号線 水単相時の静電容量測定值は圧力 $7 \mathrm{MPa}$ 条件の $20 \mathrm{pF}$ であるのに対して $18 \mathrm{MPa} て ゙ は$ 約 $1 / 20$ の $1 \mathrm{pF}$ 程度と小さく, 測定が困難となる場合があった。 信号線に生じる静電容量を消去する方法として知られ ているのは，インピーダンス補償式 4 端子信号線であ るが，本計測体系ではこの種の補償式信号線を用いて も計測が不安定となった。この理由は，C测定值が最 大となる水単相状態でも $1 \mathrm{pF}$ 程度と小さく，信号線に 微小静電容量が生じても影響を及ぼすためと考えられ る，そこで，計測線長さを短縮化するため，測定位置 の直近に LCR 計を設置して信号線に生じる静電容量の 影響を少なくした。 


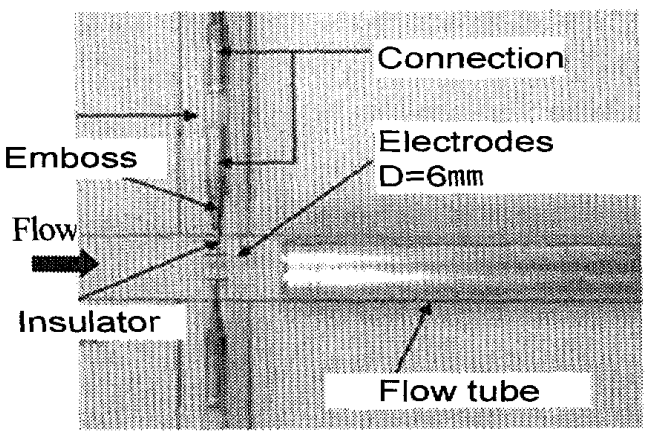

Fig. 2 MI sheath type electrode

(3) 計測回路の簡素化 電極取り付忚部の電気絶縁 不良による計測信号の迅回により，内部構造物を介して計 測信号が漏洩する可能性がある。 そこで，計測信号の漏曳 防止のため, 計測機絽電源を非接地として漏洩可路を遮断 亦ることに努めた。この過程を概今的な電気可路構成図と して図3にステップごとに示す．図3(1)は漏䇩対策前の状 態を示す. Rs は棓測回路の電流を電王信号として取り出す ための基淮抵抗であり，Vは基淮抵抗の端子間電王を示す. $2 つ$ 静電容量C1 とC2 は流路の二相流こ相当する要素で あるが，内部構造物を介し流路から接地可路に膤洩する経 路の抵抗要素RLを介して2分割される回路とした．また，

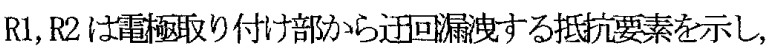
R1 は流路をバイパスする要素, R2 は電栖取り付け部と基淮 抵抗Rs 間の抵抗要素を示寸. 図3(1)ではR1, R2, RL が計測 電流こ対する計測䂴差となっている. 図3(2)は計測電源に 絶縁型トランスを用いることにより过可路Rを介しての信 号漏洩がなくなる回路を示す．困 3(3) ほ絶秝型電極(MI シ 一ス型をを採用することにより，電極取り付掊勏ら过可漏 洩する抵抗要素R $1, \mathrm{R} 2 か ゙$ 消去されて过可漏洩回路要素がな くなり, 電桖間の回路要素は流路中の静電容量C1だけとな る回路を示す，実際こは流路の二相流中にも抵拧要素があ るが，本計測ではインピーダンスの位相差を分離計測する ことにより，C成分を選択計測する手法を用いた。これによ り，計測回路の簡素化が達成された。

SN 比を増大させる有効な対策には以下の方法も考えられ る.

- 円板電極間隔を小さくし,かつ, 電極と細管内壁との間 隔を增して計測言号の过可漏电を防止する方法

- 流路中心に円板電極を配置し, 他電極として細管自体を 電極とする電極対を採用して計測領域を増大させる方 法.

（4）計測用高周波電源 C 成分計測では, 電極用 印加電源の周波数が高いほど計測感度が向上するが, 周波数帯域によっては不安定となることが実験的に確 認されている ${ }^{(11)}$. 本計測体系では $0.9 \mathrm{MHz}$ 程度以下の 周波数帯域で計測が不安定となった。この原因は計測
細管と電極で構成される相当回路で共振回路が形成さ れたためと考えられる。本計测では，信号が安定する 電源周波数に $1 \mathrm{MHz}$ を用いた。
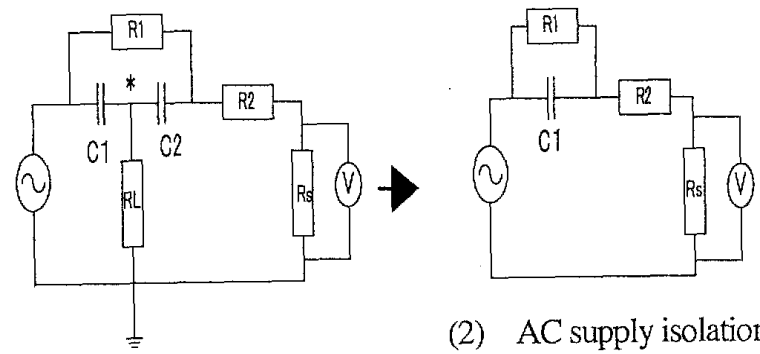

(2) AC supply isolation

(1) Original configuration

$\mathrm{C} 1, \mathrm{C}$ : Capacitance of fluid

R1: Resistance of connector

R2: Resistance of circuit

RL: Resistance of connector

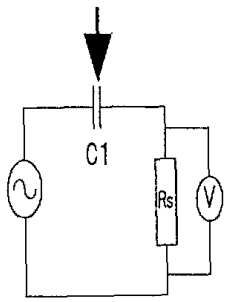

(3) Electrode isolation

Fig. 3 Conceptual electric circuit in measurement

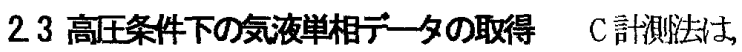
気液二相流の静電容量がボイト率と共に変化することを原 理とする方法であり，0\%(水単相)と $100 \%$ (蒸気単相)の C 測定值を基淮值とする特性式を用いてボイト率を求める方 法である. 測定開始前に気液単相のC測定值 $\mathrm{Cg}$ と C それ ぞれを演算式変換器に入力することにより，リアルタイム でボイト率を測定することができる. 既報のバンドル試験 装置 ${ }^{(10)}$ を用いた $\mathrm{Cg}$ とC の測定結果を以下に示す.

・水単相のCl 㵋定結果＼cjkstart高温になるほど，水の誘電 率は小さくなる傾的があるので，水温変化を伴うボイド率 測定では温度補正方必要となる. 物牲值として報告されて いる水の比誘電率 ${ }^{(15)}$ は，図 4 に示すように温度 $0 \sim 100^{\circ} \mathrm{C} の$ 低、温度範用だけであり，より高温条件の值さ示されてい なかかた そこで, 本試験で忹力 $2 \mathrm{MPa}, 4 \mathrm{MPa}, 7 \mathrm{MPa}$ 高王条件下て水单相の静電容量を測定し，測定結果を図 4 に示す．図 4 より，温度 $0 \sim 100^{\circ} \mathrm{C}$ 誘電率の温度依存性さ 比䡈的大きいが, 約 $200^{\circ} \mathrm{C}$ 人上の高温条件での温度依存性は

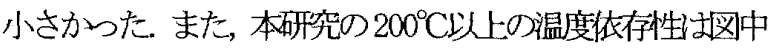
の曲線で表した，圧力 $18 \mathrm{MPa}$ の試験で飽和温度に対する 静電容量を用いた。

・蒸気単相のCg 測定結果ボイド率 $100 \%$ の值Cgは 蒸気単相の流路内・濡水壁状態のボイト率 100\%の測定值を 基淮值として用いる，図 5(1)にボイト率計 VD がボイト率 100\%に至る過程を概㖅で示す. ボイド率計地熱部辰さ の出口位置(高さ $1205 \mathrm{~mm}$ )にある. 試験では，試験部出口弁 を閉として上部し蒸気を蓄積し容器内の液面を低下させる ことによりボイド計測電極部を露出させた，図5(2)に圧力

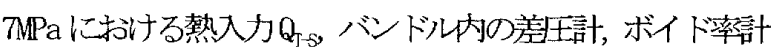


(VD) の測定結果を示寸. 図 5(2)より，Q Q $\mathrm{Q}-51 \mathrm{~kW}$ 設定後, 約 9 分後, $\Delta \mathrm{P}$ 測定値力減少し始めてボイド率計忏変動のない

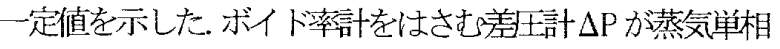
の水頭 $\rho \mathrm{gh}$ 相当の值を示すことからボイド率 $100 \%$ 状態で あることを確訫した。

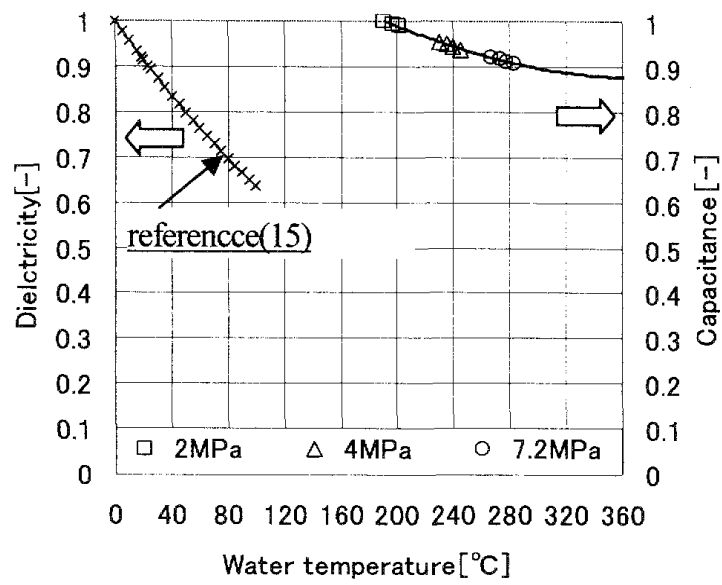

Fig. 4 Capacitance dependence on water temperature

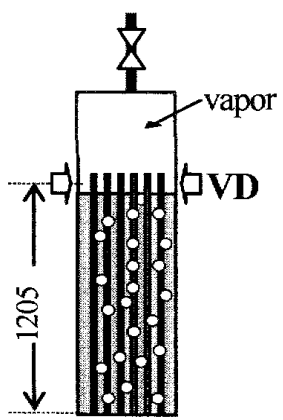

Fig. 5(1) Exposure profile of electrode in test section

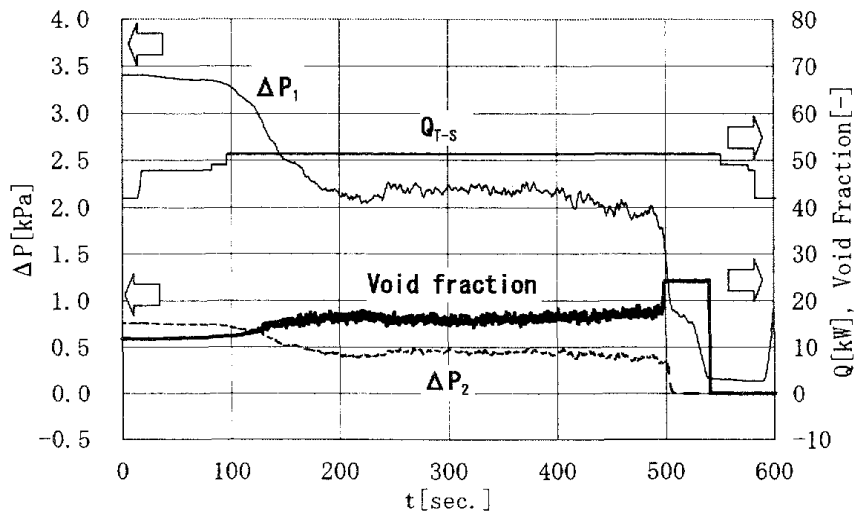

Fig. 5(2) Measured result of void fraction and $\Delta \mathrm{P}$

2.4 圧力 $18 \mathrm{MPa}$ 条件下のC 計測法によるボイド率

測定結果 2.1 に示した FBR の蒸気発生器細管を模 擬した円管試験装置にボイド計測部を取り付け，軽水 炉炉心㽵力条件よりさらに高圧の $18 \mathrm{MPa}$ 条件において ボイド測定を行った。図 6 に加熱量一定, 質量速度 473 $\sim 1892 \mathrm{~kg} / \mathrm{m}^{2} \mathrm{~s}$ に対する測定結果を示す.
高王条件では，䭂和温度が高くなると共に気液の密度比 (静電容量比) は小さくなり，原理的に計測感度が低下す る. 本計測こおういも，水温度が $356^{\circ} \mathrm{C}$ 上臨界温度 $374^{\circ} \mathrm{C}$ に 近い高温となるため，ボイド率 $0 ， 100 \%$ に相当するC測定 值はそれぞれ，2pF，0.1pF と気液の静電容量比は小さくな った ボイド率0〜100\%のボイド率は，気液単相のC測定 值を次式大内禹することにより次の(2)式で求める(16).

$$
\begin{aligned}
& \frac{I}{I_{\alpha=0}}=\frac{1-\alpha}{1+0.5 \alpha} \quad \text { (Maxwell } の \text { 式) } \\
& \alpha=\frac{1-C^{*}}{1+0.5 C^{*}} \quad(\mathrm{C} \text { 計測法) } \\
& C^{*}=\frac{C(\alpha)-C_{\alpha=100}}{C_{\alpha=0}-C_{\alpha=100}}
\end{aligned}
$$

このように小さなC測定值変化の範囲内でボイド率 測定を行わなければならないため，計測感度の向上が 必要となる. R 計測法と同様に，高温水中で長期間， 電極を使用すると計測感度が低下する傾向があり， R 計測法では計測不能となったがC計測法では計測感度 が低下するだけで計測は可能であったまた，ボイド 率計は流れ方向の異なる位置 (2 䇢所)に設置したが, ボイド率計の電源周波数が商用電源周波数 $(50 \mathrm{~Hz})$ の整 数倍になると交流の同調現象が発生し，信号が不安定 となる，そこで，電源周波数を $50 \mathrm{H} \mathrm{z}$ と異なる周波数 に設定することにより同時測定が可能となった.

図6より，ボイド率測定結果は下流側でボイド率が 大きくなり，また加熱量一定の条件で質量速度が減少 するとボイド率が高くなる傾向が測定された。

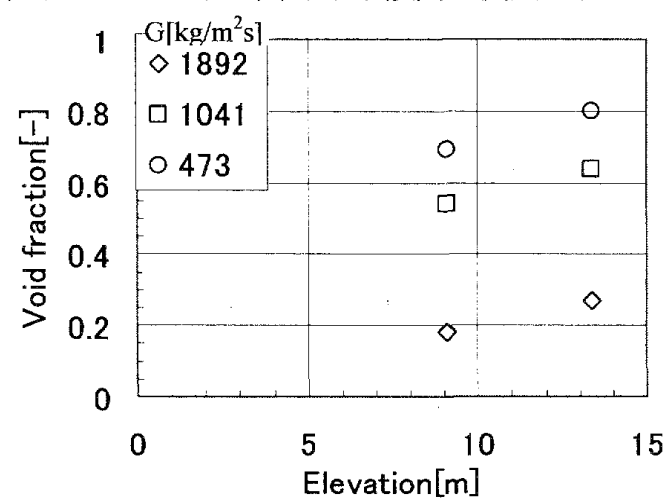

Fig. 6 Void fraction measurement result of steam generator two phase flow tube (18MPa) in pressure, $q$ " $=170$ $\mathrm{kW} / \mathrm{m}^{2}$ in heat flux)

\section{3. 高王条件下のC計貺法の妥当性確諰}

C 計測法によるボイド率測定徝の妥当性を確訫するため, 急速庶断弁によるボイド率計測法の測定值と比較した。ボ イド率測定を行った試験部は， $\mathrm{C}$ 計測法が 37 本バンドルの $7 \mathrm{MPa}$ 加熱体系，急速遮断弁による方法が 19 本バンドルの 
非加熱体系である. 図7に37 本バンドル，図8に19本バ ンドル試験部の概要を示す，それぞれの試験部形状寸法を 下記こ示す．ここで水力等価直径はロッド 1 本当たりの值 を示す.

Table 1 Test section geometries measured with $\mathrm{C}^{-}$and Q. S. method

\begin{tabular}{|c|c|c|}
\hline Measurement method & C-method & Q.S. method \\
\hline Number of rods & 37 & 19 \\
\hline Outer rod diameter[mm] & 13 & 12 \\
\hline Rod gap[mm] & \multicolumn{2}{|c|}{1.3} \\
\hline Hydraulic diameter[mm] & 4.34 & 4.25 \\
\hline
\end{tabular}

2 つのバンドル体系はロッド外径が少し異なるが，37 本 体系は中心ロッドを含む六方格子配列の 4 層配列であり， その内側の 3 層部分が 19 本体系である. 水力等価直径がや や異なるが，その差異が及ぼす流路断面平均ボイド率への 影響拄，ボイド率評価によく用いられるドリフトフラック スボイド辛相関式(14)により，クォリティ 5\%以上において 高々 $1 \%$ と小さこと評価された ただし，後述するように 発熱非発熱の及ぼすボイト率分布の影響さ測定結果の差異 に見られた 圧力条件は $18 \mathrm{MPa}$ が望ましいが，急速遮断弁 によるボイト率測定が難しいので2MPaとした。

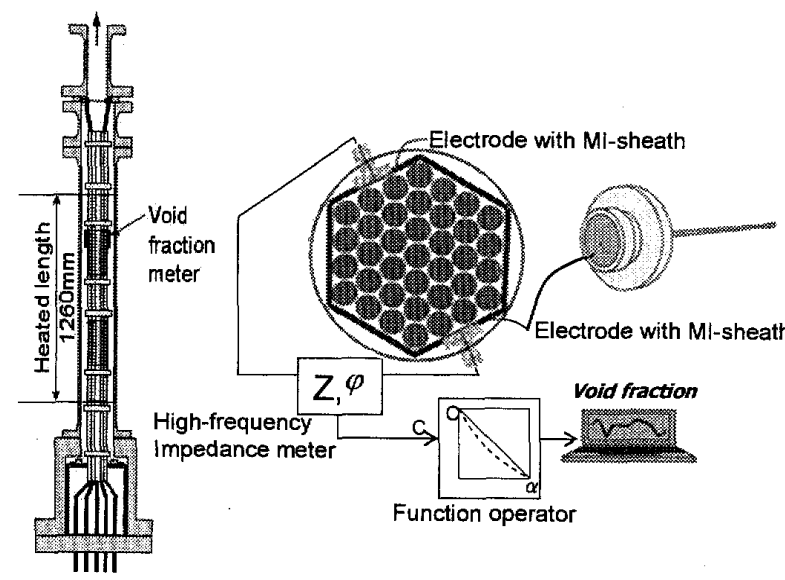

Fig. 737 Bundle and measurement system ${ }^{(1)}$

3.1 C計測法によるボイド率測定Ｃ（計測法によ るボイド率計は図 7 に示すように值径 $25 \mathrm{~mm}$, セラミ ック製の電極対を圾験流路内面に対向するように取り 付けた. 電極に LCR 計を用いて高周波定電圧を印加し, 二相流のC 成分を測定した.

\section{2 急速庶断弁の閉じ込め法によるボイト率溳定}

急速庶断弁によるボイド率棓十浿性では，流体を瞬時に封止 する高速可転板(Quick Shut Valve：Q.S.)を用いて流体を 封じ込めて水量を差王計測により測定する. 校正圾験部 封 止部)は図に 8 示寸ように，高さ力向に陌間部の計量誤差 評価上， 2 分割構造としており上部長さは下部長さの $1 / 2$ である.

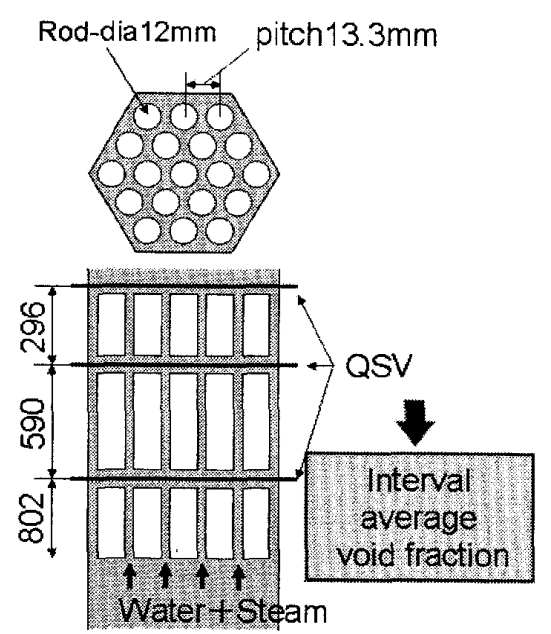

Fig. 8 Test section with quick-shut valve(QSV) for void fraction measurement ${ }^{(10)}$

3. 3 C 計貺法と Q. S. 法のボイト事の相互比較 Q.S. 法と

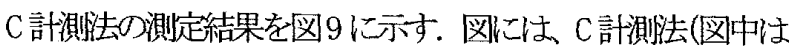
C) と急速庶䉼弁閉じ込め法(図中は Q. S.)によるボイド率測 定結果、対数関数で近似した曲線及ひ雨者の差(C-Q.S.)を示 し、それぞれのボイド率測定值の比較が可能なようにした。

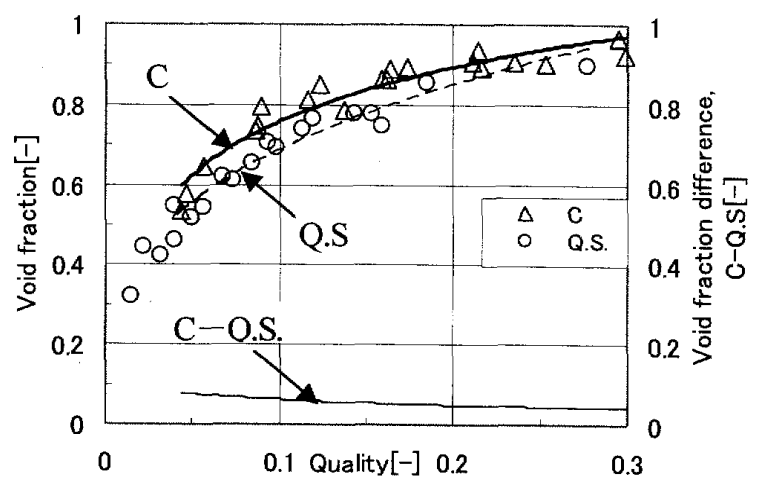

Fig. 9 Compared result between $C$ and Quick-shut valve method void fraction method $\mathrm{s}(2 \mathrm{MPa}$ in pressure, $400 \sim 2000 \mathrm{~kg} / \mathrm{m}^{2} \mathrm{~s}$ in mass flux) ${ }^{(10)}$

図9より，両者で測定されたボイド率とクォリティとの関係 はよく似ているが, 傾向的にC 計測法のボイト率がQ.S.法よ り大きい傾向を示した，両者のボイド率偏差を図中にC 貺定 值一Q.S法測定值(C一Q.S.)で示寸が，クォリティ0.05付近で 最も差異が大きく、クォリティが増すと共に雨者は濑近し， 差異は 4\% 8\%の範用であった 差異が生じる原因として考 えられるのは，C計測法の37本バンドル試験部代発熱体系, Q.S.法の 19 本ベンドル試験部汴非発熱体系という発熱条件 の羑異が考えられる. 発熱系では各ロッドからの出力分布が 一様であるため, 断面内のボイド率分布は比輅的一様こ近、 と考えられるが，非発熱体系では流路中央で大きく，流路畦 付近は小さくなる傾向があると考えられる. その結果として Q.S.法の断面平均ボイド率が小さくなったと考えられる 図9より，C計測法によるボイト率計測法の妥当性は一定の 
範井て確認することができる。圧力条件は $2 \mathrm{MPa}$ であるが， 飽和水の静電容量は水の温度に比例して連続的に緩やわ水に 変化する.したがって，図9で評価したC計測法によるボイ ド率計測法の妥当性が $18 \mathrm{MPa}$ の压力条件に適用するとみな しても誤りでなないと考えられる.

\section{4 特性式力汉曲線特性となる等佃回路の描像 こ} れまでに述べた一般的な流路の気液一相流に対する C 計測 法の特性式は双曲線関数となるが，これを電気可路的に理 解するため等㑋可路を推定し，図 10 に示す。双曲線状特性 となる場合としては，計測部空間内の気液一相流のインピ ーダンス・C成分が多数の直列力乔列に接続した，外側境 界部に向けてC成分が漸咸するような太鼓型の合成可路が イメージされる. これから, 図10右の特性線过直線 : C $C^{*}=C$ $\alpha$ (Cの並列回路) と双曲線: $C^{*}=\alpha / C(C$ の直列回路)の間に 位置するような双曲線と見做せることから図示した等価回 路を描像した。ま，別途実施した異なる電極体系（流れ 力向にリング状電極対を設置した体系) の特性試験結果 ${ }^{(12)}$ では植線となることを確認しているが，この場合は計測領 域・境界が一定でインピーダンスが備椷することがないた めと考えられる.この結果から，双曲線関数特性となるの は空間内のボイド率を対向設置した電極で計測する電極体 系の特性であると考えられる.

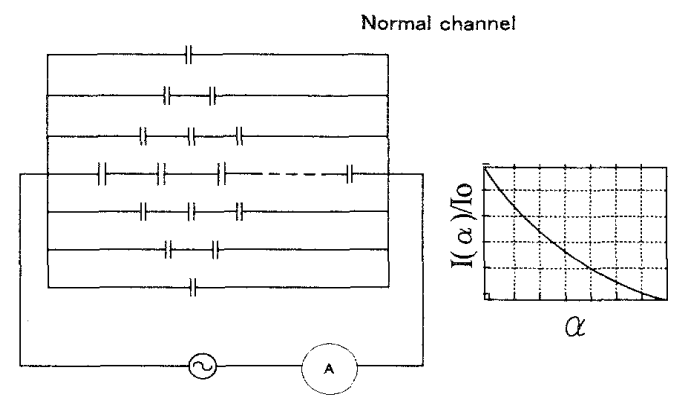

Fig. 10 Equivalent circuit of void fraction measurement with capacitance method

\section{4. まとめ}

本研究では，静電容量検出式ボイド率計(C 計測法)を 高温高圧条件一適用し, 以下の結果が得られた。

1. セラミック端子付MI シース型電㢦部により, 而搞温・ 而搞王・電気絶縁性・耐久性を確保与る静電容量検出 型(C計測法)ボイド率棓測部を設計した。

2. 1.のボイド率計測用電極部・信号線からなる計測 回路の簡素化を行い，圧力 $18 \mathrm{MPa}$ 条件のボイド率 を測定した。

3. 急速遮断弁法によるボイド率測定值と C 計測法に よる測定值を圧力 $2 \mathrm{MPa}$ 条件で比較した. 加熱系と非加
熱系の差異が及ぼすボイド率への影響が見られたが,C 計測法によるボイド率測定值の妥当性が確認できた。

\section{謝辞}

本研究の実施に際して，日本原子力研究開発僟構・工務 技術部工作技術課の方々，エネルギーシステム研究部大貫 晃氏(現 三菱重工 (株)), 玉井秀定氏, 助川電気工業 (株) 及びアート科学 (株) にご協力ただきました。ここに記 して感铸の意を表します。

\section{文献}

(1) Atomic Energy Society of Japan ed., Multiphase Flow Measurement Method(in Japanese), (2003), Morikita Publishing Co., Ltd.

(2) Cimorelli, L. and Evangelisti, R., The application of the capacitance method for void fraction measurement in bulk boiling conditions,

International Journal of Heat and Mass Transfer, Vol. 10(1967), pp. 277-288.

(3) Mi, Y. , Ishii, M. and Tsoukalas, L.H. Investigation of vertical slug flow with advanced two-phase flow instrumentation, Nuclear Engineering and Design, Vol. 204(2001), pp. 69-85.

(4) Inoue, A., Kurosu, T., Aoki, T., Yagi, M., Mitsutake, T. and Morooka, S., Void fraction distribution in BWR fuel assembly and evaluation of subchannel code, Journal of Nuclear Science and Technology Vo. 32, No.7( 1995), pp.629-640.

(5) Hori, K., Akiyama, Y., Miyazaki, K., Kurosu, T. and Sugiyama, S., Void fraction in a single channel simulating one subchannel of a PWR fuel assembly, Two-phase flow modeling and experimentation (1995).

(6) Watanabe, H. , Iguchi, T. and Kimura, M. Development of conductance-type void fraction meter, JSME annual meeting, No.4(2002), pp.233- 234

(7) Watanabe, H. , Iguchi, T., Kimura, M. and Anoda, Y., Development of quick-response area averaged void fraction meter, JAERI-Research 2000-043 (2000).

(8) Iguchi, T., Watanabe, H. , Kimura, M. and Anoda, Y., Development of quick-response area averaged void fraction meter - application to BWR condition-, JAERI-Research 2001-032 (2001). 
(9) Asaka, H. , Iguchi,T., Watanabe, H. , Nakamura, H. and Sagawa, J., Development of high pressure conductance type void fraction meter for transient boiling experiments, Proceedings of Fall meeting of the Atomic Energy Society of Japan(2003), F46.

(10) Watanabe, H., Mitsutake, T., Kakizaki, S. and Takase, $\mathrm{K}$, Experimental study on feasibility of capacitance void fraction meter, Transactions of the Japan Society of Mechanical Engineers, Series B, Vol. 74, No.742 (2008), pp. 435-436

(11) Watanabe, H. , Mitsutake, T., Kakizaki, S. and Akimoto, H, Electro-void fraction meter development and application to tight lattice rod assembly within reduced moderation water reactor, Proceedings of the $9^{\text {th }}$ National symposium of power and energy systems(2004), pp.69-70.

(12) Watanabe, H., Mitsutake, T., Kakizaki, S. and Takase, K, Experimental study on feasibility of capacitance void fraction meters, Proceedings of the $13^{\text {th }}$ National symposium of power and energy systems (2007), pp.77-78.

(13) Tamai, S. , Takase, K., Shibata, M. and Hayafune, H., Flow instability experiments on steam generator with straight double-walled heat transfer tube for FBR

(2) Experimental Results under High Pressure Conditions, 2007 Fall Meeting of the Atomic Energy Society of Japan, K58, (2007).

(14) Kureta, H. , Yoshida, H., Tamai, H., Ohnuki, A. and Akimoto, H., Thermal-Hydraulic Estimation in Tight-Lattice Rod Bundles for Development of the Innovative Water Reactor for Flexible Fuel Cycle, Progress in Multiphase Flow Research 3, (2008), pp.99-109.

(15) The Society of Chemical Engineers, Japan, Chemical engineering handbook(in Japanese), $5^{\text {th }}$ edition, (2004), Maruzen Co., Ltd

(16) Maxwell, J. C. , A treatise on electricity and magnetism, 3rd ed. ,(1954), Vol. 1, Chapter 9, Article 314, Dover, New York 